Article

\title{
Environmental Performance of Eastern Canadian Wood Pellets as Measured Through Life Cycle Assessment
}

\author{
Alejandro Padilla-Rivera ${ }^{1, *}$, Julie Barrette ${ }^{2}$, Pierre Blanchet ${ }^{1}$ and Evelyne Thiffault ${ }^{3}$ \\ 1 NSERC Industrial Research Chair on Ecoresponsible Wood Construction, \\ Département des Sciences du Bois et de la Forêt, Université Laval, 2425 Rue de la Terrasse, \\ Pavillon Abitibi-Price, Québec, QC G1V 0A6, Canada; pierre.blanchet@sbf.ulaval.ca \\ 2 Natural Resources Canada, Canadian Forest Service, 1055 du P.E.P.S., P.O. Box 10380, Stn. Sainte-Foy, \\ Québec, QC G1V 4C7, Canada; julie.barrette.1@ulaval.ca \\ 3 Renewable Materials Research Center, Département des Sciences du Bois et de la Forêt, Université Laval, \\ 2405 rue de la Terrasse, Pavillon Abitibi-Price, Université Laval, Québec, QC G1V 0A6, Canada; \\ Evelyne.Thiffault@sbf.ulaval.ca \\ * Correspondence: Alejandro-de-jesus.padilla-rivera.1@ulaval.ca; Tel.: +1-418-656-2131
}

Received: 20 July 2017; Accepted: 14 September 2017; Published: 19 September 2017

\begin{abstract}
Global demand for renewable energy has increased drastically over the last decade due to new climate change policies implemented in many jurisdictions. Wood pellets made from primary wood processing mill residues represent an attractive source of renewable energy that can be used in the environmental global challenge. However, the environmental impacts involved in their manufacture must be considered to measure the real benefits they can provide to the atmosphere. The general aim of this study was to evaluate the environmental impacts of wood pellet production at two Quebec plants using the Life Cycle Assessment (LCA) methodology and considering a gate-to-gate approach. The paper focuses on the different stages involved in wood pellet production; from the recovery of mill residues, through the pelletization process, to pellet bagging. The paper further expands to a cradle-to-grave analysis comparing the environmental footprints of producing and combusting $1 \mathrm{GJ}$ of energy from wood pellets, natural gas and fossil fuel oil. The analysis suggested that the drying and the pelletizing stages were the largest negative factors affecting the environmental performance of wood pellet production. The comparison demonstrated the environmental advantage of using renewable rather than fossil sources of energy. Considering the growing interest in renewable energy, biomass in particular, and the lack of environmental information on wood pellets, this study could be useful not only for forest sector-related industries but also for the energy sector and policymakers.
\end{abstract}

Keywords: life cycle assessment; wood pellets; renewable energy; biomass

\section{Introduction}

There is growing interest worldwide in renewable energy due to environmental and economic concerns. As one of the major renewable options, biomass is increasingly utilized to produce different forms of energy. Considered a carbon carrier capable of storing energy and releasing it on demand, it represents an attractive energy source [1]. Wood, a bio-based material, has been recognized by the Intergovernmental Panel on Climate Change [2], the International Energy Agency [3] and the International Renewable Energy Agency [4] as a key resource to fight climate change and secure energy demand in the global challenge.

Wood pellets are currently the preferred form of biomass for effective heating, and demand for them has increased rapidly over the last decade [5]. The pelletizing process offers a number of benefits; 
it increases the energy density of the biofuel, reduces handling, storage and transportation costs, and improves overall biomass quality and durability [6]. Demand for wood pellets is anticipated to expand due to government support for renewable sources. For example, the European Commission's Renewable Energy Directive has committed to achieving a 27\% share of renewable energy in total energy consumption across its member states by 2030 [7]. In addition, it is expected that $42 \%$ of renewable energy will be obtained from biomass, such energy being used for heating, cooling and electricity generation.

In Canada, wood pellet manufacturing is bringing significant value to the domestic forest sector. As of the beginning of 2013, Canada had 41 pellet plants with over 3 million tonnes of annual production capacity, the province of Quebec being the second largest producer, with 19\% of the total Canadian production capacity. Wood pellet production is a key segment of the bioenergy sector and an important part of the provincial strategy for growing Quebec's natural energy advantage.

In view of such increasing demand for woody biomass [8], specifically wood pellets [7], and of their key role in environmental policies relating to renewable energy, there is an emerging interest in quantifying the environmental impacts derived from wood pellet production. The Life Cycle Assessment (LCA) methodology has proven to be one of the most valuable tools for carrying out the environmental impact analysis of any system or product from cradle to grave [9]. The results and findings of an LCA could provide useful recommendations for decision-making.

The literature on wood pellets has already considered the environmental impact of pellet transport [10] and pellet combustion using different small-scale boilers [11]. However, there is a lack of information on the environmental profile of the pellet production stage. Kylili et al. [9] and Laschi et al. [12] environmentally compared pellet production with other forms of energy following a life-cycle approach, and using industrial forests as the source of the raw material supply. To our knowledge, there seemed to be no studies on the environmental profile of high-quality pellet production for residential heating. Moreover, there were no studies dealing with the specific case of Quebec's wood pellet production.

The main goal of this study was to evaluate the environmental impacts of producing wood pellets in Quebec following the Life Cycle Assessment (LCA) methodology, and considering a cradle-to-grave approach. Pellets may be manufactured either on production lines located at a primary wood processing plant or in a plant dedicated exclusively to pellets. This LCA included both cases. It was based on average and/or representative production characteristics and product values observed in two Quebec production facilities. It focused on the different steps of wood pellet production: from the recovery of mill residues to the pelletization process and on to pellet bagging. For the cradle-to-grave analysis, the combustion of wood pellets for energy in boilers was included in the assessment.

\section{Materials and Methods}

LCA is an environmental assessment tool that aims at analyzing the environmental effects associated with a product, process or single activity over the entire course of its life or duration, i.e., from cradle to grave. The International Organization for Standardization (ISO) has published procedures for conducting LCA [13], which provide specific guidelines. Such assessments are based on the development of a system model that quantifies the inputs (consumption of energy and materials) and outputs (emissions and wastes) released to the environment throughout the entire life cycle of the system. In this study, the ISO 14040 guidelines were applied to assess the environmental effects of wood pellet production from a cradle-to-gate perspective.

\subsection{Description of the Case Study}

Wood pellets are composed of fine wood particles compressed into cylindrical shapes through a process called pelletization. They can be used on different scales, from residential heating in small boilers to industrial applications such as power plants. Quality requirements vary with the different applications, and quality standards specific to individual markets are in full development. According 
to a Canada Bioenergy data survey [14], Quebec is the second largest wood pellet producer in Canada, and its nine plants represented 625,000 tonnes of pellets (an average of 69,444 tonnes per plant) in 2013.

For this study, the Quebec Wood Export Bureau (QWEB) chose two of Quebec's nine plants as case studies. Both plants were considered representative of the Quebec production sector, with around 60,000 tonnes of capacity each in 2013. Producer 1 operated on hardwood residues while Producer 2 was based on softwood residues.

The research was based on the production of packed wood pellets made from wood chips and residues from Quebec-based industrial primary wood processing plants. The functional unit reflects the function of the product under study and helps, as a reference flow, to report the environmental results; therefore, the functional unit of this LCA study was chosen to be one metric tonne $(1 \mathrm{t})$ of packed wood pellets.

\subsection{System Boundary Description}

Figure 1 presents the system boundary for the gate-to-gate Life Cycle Inventory (LCI) analysis of wood pellet production based on the functional unit described above. The production chain under evaluation was divided into five main subsystems. The pellet production boundaries cover gate-to-gate emissions, energy, water and materials necessary to meet the product system requirements. The subsystems included in the wood pellet production process were as follows: drying, grinding, pelletizing, cooling and packing.

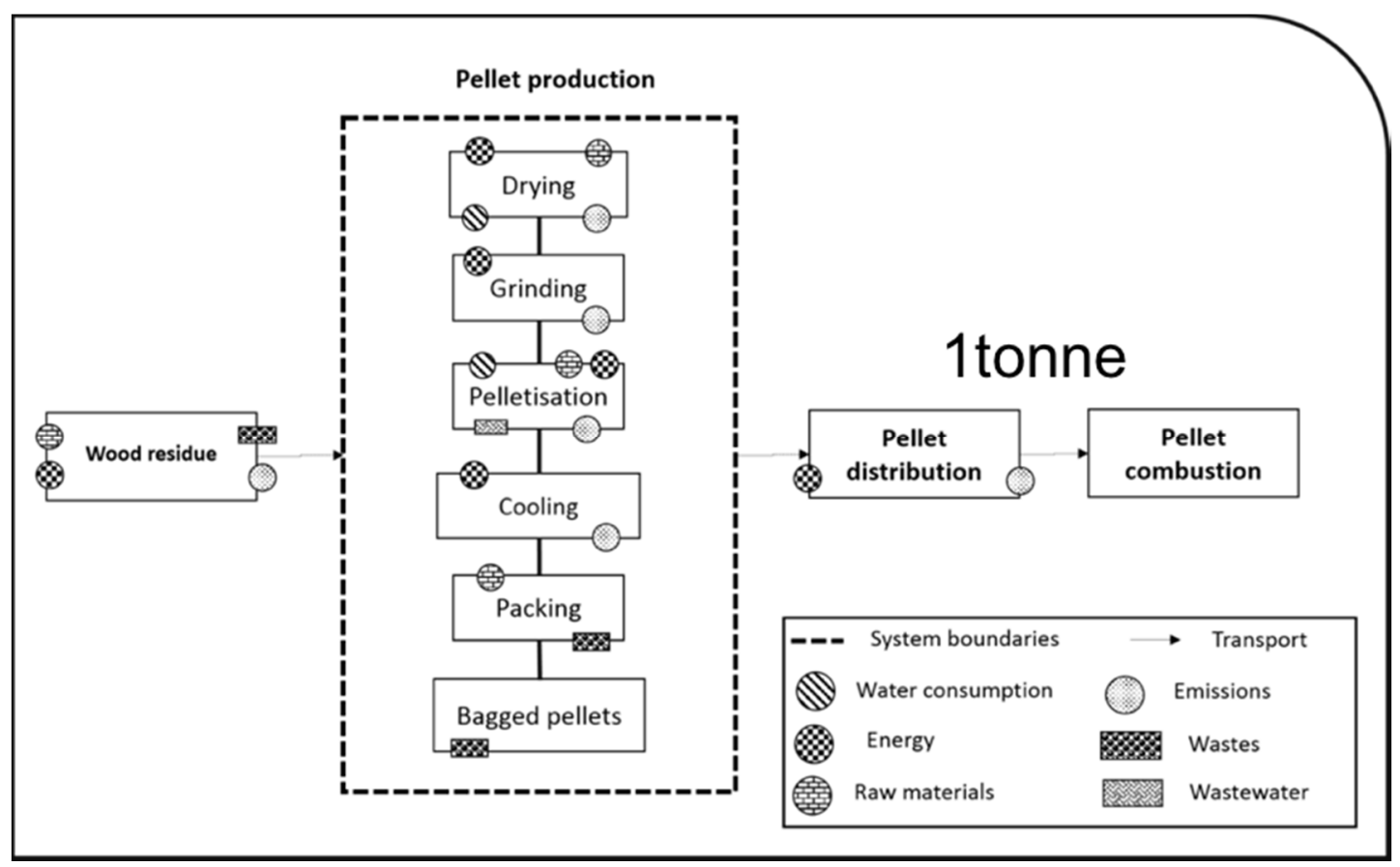

Figure 1. Wood pellet production chain under assessment.

The pelletization system boundary covered the cradle-to-gate emissions, which means including emissions generated for material and energy produced off-site, such as grid electricity that is used on-site, including cradle-to-gate emissions for sawmill or wood residue production. Our analysis does not include either the transport of the sawmill residues to the pellet mill, which means that only emissions starting at the pellet mill and emissions related to the production of wood pellets were considered.

Life cycle data for wood residue production were provided on a mass allocation basis. Raw material is collected on-site from a connected but separate wood processing facility. In this case, we assumed that about 70 to 80 percent of wood leaving the wood manufacturing process is converted 
to main wood product in the form of timber and pulp; the remainder (sawdust, planer shavings, trim blocks, and edging strips) is available for the pellets process; therefore, the wood residue carries 20 to 30 percent of the burden from the wood manufacturing process [15].

Sawmill residues in the form of sawdust and shavings, were at one time considered waste, but has over the years changed into an interesting resource for energy products, panel and pulp manufacturers [16]. Nowadays, the wood pellet industry uses a large share of the sawmill residues in Canada. In the future, competition between bioenergy options may reduce the accessibility of sawmill residues for wood pellets production [17] and we may look at other types of wood biomass such as salvaged logging or harvest residues to produce wood pellets [18,19].

Some of the raw material used in the production of wood pellets must first be dried. The moisture content of the material will vary according to its origin. For example, wood chips tend to be wet (50\% to $55 \%$ moisture content on a dry basis (MC)), while wood shavings are usually very dry $(5 \%$ to $10 \%$ MC on a dry basis) and may not require a drying step. Different types of fuels can also be used to feed the dryer. In this research, Producer 1 used natural gas while Producer 2 relied on sawmill in-house residues (sawdust, slabs and planer shavings).

Once the material has been dried to reach about $10 \% \mathrm{MC}$ on a dry basis, it must be ground, unless the granulometry (or particle size) is already adequate for pelletizing. The dried material is fed to the hammer mill, where it is comminuted into a finer and uniform material, as necessary to produce high-durability pellets. Producer 2 only ground $20 \%$ of its raw material while Producer 1 ground all of its material.

In the next step, pelletization, the dry and uniform particles are compressed into pellets. Screws feed the raw material into the granulation units (or pellet mills), which operate at high pressure and temperature to soften the lignin, wood's natural binder, thus enhancing cohesion between the wood particles and binding them together. Producer 2 used two granulators (Producer 2) while Producer 1 used three. A binding agent may be added to improve pellet quality. This was the case with Producer 1 , who used a vegetal lubricant as well as some water to facilitate the process. Producer 2 used only water.

When the pellets leave the granulators, they are hot and need to be cooled down to ambient temperature before being packed in plastic bags. Both producers used the most common cooling technology, which simply relies on running a counter airflow current through the pellet flow. This operation also reduces the moisture accumulated during the densification step, and enhances pellet durability and storage stability.

In the final step, packing, the pellets are poured into bags. Producer 1 used a robot to bag the pellets while, with Producer 2, packing was performed manually. The bags of wood pellets are finally stored in the mill's wood yard with a forklift truck that operates on either diesel or propane.

Throughout the process, electric conveyors and screws are used to transport the material. A dust collector that runs on electricity is also part of the system. The annual consumables, i.e., the resources needed to run the various subsystems, were derived from information provided by the two producers, and they have been included.

\subsection{Data Sources}

Inventory data collection for the pellet manufacturing process under assessment was based on annual production statistics provided by the participating plants. The main data and processes regarding the machines are reported in Table 1, as are the data on fuels, electricity, plastics, emissions and wastes used or generated in the different sub-processes considered within the system boundary. All data reported in this table correspond to primary data regarding the pellet production system. They were mostly taken from the Ecoinvent 3.1 database ${ }^{\circledR}$ processes (Ecoinvent, Zürich, Switzerland) and US LCI database, which were then partially adapted with data from the participating producers. A few processes were modified to suit Quebec circumstances, for example, European electricity was replaced with Quebec grid energy sources. 
Table 1. Processes and sub-processes included in or excluded from the system boundaries for the LCA (gate-to-gate).

\begin{tabular}{|c|c|c|}
\hline Life Cycle Assessment Stages & Processes/Sub-Processes & Comments \\
\hline Wood residue & $\begin{array}{l}\text { Residue collection and } \\
\text { transportation to site of } \\
\text { production }\end{array}$ & $\begin{array}{l}\text { Consumption of electricity, fossil fuels (direct } \\
\text { and indirect emissions) and direct emissions } \\
\text { to the environment. Excluded }\end{array}$ \\
\hline Pellet production & $\begin{array}{l}\text { The pelletization system } \\
\text { boundary includes: drying, } \\
\text { grinding, pelletizing, } \\
\text { cooling and packing }\end{array}$ & $\begin{array}{l}\text { Electricity consumption (direct and indirect } \\
\text { emissions) and direct emissions to the } \\
\text { environment. Included Consumption of diesel } \\
\text { and certain consumables (oils, blades, etc.) } \\
\text { and production of equipment (direct and } \\
\text { indirect emissions). Included }\end{array}$ \\
\hline Pellet distribution & $\begin{array}{l}\text { Transportation of packed } \\
\text { pellets to clients }\end{array}$ & $\begin{array}{l}\text { Direct and indirect emissions. } \\
\text { Transportation, Excluded }\end{array}$ \\
\hline Pellet combustion & $\begin{array}{l}\text { Heat production and waste } \\
\text { management }\end{array}$ & $\begin{array}{l}\text { Production of certain consumables, Direct } \\
\text { emissions to the environment and Production } \\
\text { of certain consumables. Included }\end{array}$ \\
\hline
\end{tabular}

It is included in the expansion to a cradle-to-grave analysis comparing the environmental footprints of producing and combusting 1 GJ of energy from wood pellets, natural gas and fossil fuel oil.

Human activity, capital equipment and infrastructure were excluded from the system boundary. This is because the data collection required to properly quantify human involvement is particularly complicated. The allocation of such flows within production and uses, as opposed to other societal impacts, was also not feasible for a study of this nature, and it is not expected to be significant anyway. Moreover, the environmental effects of capital equipment, which include manufacturing, installation and buildings have generally been shown to be of minor importance relative to the materials and components used over the entire useful lives of the buildings and equipment [20].

\subsection{Impact Categories and Impact Assessment Methods}

Impact assessment methods are used to convert product life cycle inventory data into potential environmental impacts. In this study, we opted to present the results according to the ReCiPe Midpoint (H) method [21]. This method offers the possibility to aggregate the results of the inventory according to an intermediate characterization of the impacts (midpoint impact) or to further push the aggregation by carrying out an endpoint impact characterization.

ISO 14040 does not specify any methodology or support value choices to group impact categories. However, since this study is focusing on packed pellets, five impact categories were selected to reflect global impacts. They related to the specific characteristics of the wood pellet industry in Quebec, and took into account the overall impacts in the transportation and energy sectors [9]. The categories of impacts selected were: climate change and depletion of the ozone layer, human toxicity, reduction of water supplies and fossil depletion (reduction of fossil fuels). These impact categories are in line with most of the studies carried out to evaluate the environmental performance of wood pellets focusing on climate change, abiotic depletion potential, ozone depletion potential and human toxicity $[9,16,22-25]$.

The climate change, depletion of the ozone layer and reduction of fossil fuels impact categories are selected for the analysis of this paper, since they are among the most significant environmental concerns with regard to the energy sector [9]. Climate change is one of the most applied environmental impact indicators in LCA studies, and is a relative measure of how much heat a greenhouse gas traps in the atmosphere in terms of carbon dioxide equivalent which is found among the current most alarming environmental concerns. Also, the human toxicity impact category is selected as it results in potential risk of the chemical in humans due to emissions of primary particle, that are related with the particle matter formation (respiratory effects) [25]. 
In addition to these impact categories already described, the inputs (electricity, water, fuels etc.) associated to them were analyzed in detail to know their contribution in each impact category in terms of contribution percentage (\%).

\subsection{Life Cycle Inventory (LCI)}

LCI serves to establish the model to simulate the technical system, and at the same time calculate mass and energy flows in the system boundary. Each of the processes under evaluation (Figure 1) represent the data to be collected to calculate the environmental loads in relation to the functional unit.

In this study, the primary data were managed and collected from various sources, including surveys and questionnaires with forest managers, specific reports and LCI data from LCI databases. For the survey of wood pellet manufacturers, all Quebec pellet producers were contacted through QWEB and sent LCI questionnaires in the summer of 2016. Two producers responded with complete data in terms of pellet production, raw materials, electricity and fuel use. The LCI data were based on the 2014 annual production statistics of the participating producers. The survey served as the main tool for the inventory collection (gate-to-gate). The study considered only pellet production, which means that only inputs and outputs related to pellet production were considered.

A summary of the LCI data sources used to model the upstream impacts from energy and materials consumption during gate-to-gate pellet manufacture is shown in Table 2. A separate electricity profile for Quebec was created considering the latest grid make-up of energy sources published by Environment Canada in 2011 (see Table 2 for energy sources and composition). The electricity profile for Quebec is in line with the grid make up of energy sources data available in Ecoinvent database. As previously reported, for missing or incomplete information, data were supplemented by standard data based on the generic products under study; additionally, some operations were necessary to adapt Ecoinvent v3.1 to the local context. Table 2 summarizes the main data used in this inventory. It shows the inputs and outputs of all system elements used to manufacture 1 tonne of wood pellets.

Table 2. Summarized data, quantities and sources used for LCI (1 tonne of packed pellets).

\begin{tabular}{|c|c|c|c|c|}
\hline Parameters & Producer 1 & Producer 2 & Database & Comments \\
\hline \multicolumn{5}{|c|}{ Inputs } \\
\hline Electricity $(\mathrm{kw} \cdot \mathrm{h})$ & 163 & 93.7 & $\begin{array}{l}\text { Ecoinvent } 3.1 \text { adapted to } \\
\text { Quebec conditions }\end{array}$ & $\begin{array}{c}\text { An electricity profile for Quebec } \\
\text { was created using local data }\end{array}$ \\
\hline Water (L) & 0.20 & 0.20 & $\begin{array}{l}\text { Ecoinvent } 3.1 \text { adapted to } \\
\text { Quebec conditions }\end{array}$ & $\begin{array}{l}\text { Estimation based on surveys } \\
\text { from producers }\end{array}$ \\
\hline Diesel (MJ) & 3.22 & $\longrightarrow$ & Ecoinvent 3.1 Global data & $\begin{array}{l}\text { Estimation based on surveys } \\
\text { from producers }\end{array}$ \\
\hline Natural gas (MJ) & 1400 & . & $\begin{array}{l}\text { Ecoinvent } 3.1 \text { United } \\
\text { States data }\end{array}$ & $\begin{array}{l}\text { Estimation based on surveys } \\
\text { from producers. } \\
\text { North American database }\end{array}$ \\
\hline Lubricants $(\mathrm{kg})$ * & 0.5094 & 0.00654 & $\begin{array}{l}\text { Ecoinvent } 3.1 \text { United } \\
\text { States data }\end{array}$ & $\begin{array}{l}\text { Estimation based on surveys } \\
\text { from producers. } \\
\text { Lubricating oil used }\end{array}$ \\
\hline Bags (plastic) (kg) & 2.76 & 3.078 & $\begin{array}{l}\text { Ecoinvent 3.1 United } \\
\text { States data }\end{array}$ & $\begin{array}{l}\text { Estimation based on surveys } \\
\text { from producers. Polyethylene } \\
\text { used for packing }\end{array}$ \\
\hline Others (propane) (MJ) & - & 14.7 & $\begin{array}{l}\text { Ecoinvent } 3.1 \text { United } \\
\text { States data }\end{array}$ & $\begin{array}{c}\text { Estimation based on surveys } \\
\text { from producers. } \\
\text { North American database }\end{array}$ \\
\hline
\end{tabular}

* Producer 1 vegetable oil, Producer 2 fossil oil. LCI: Life Cycle Inventory.

\subsection{Life Cycle Impact Assessment (LCIA) Methodology}

The environmental assessment conducted in this study relied on characterization factors from the ReCipe Midpoint v1.07 method for the following impact categories: CC (climate change), OD (ozone depletion), HT (human toxicity), FD (fossil depletion) and WD (water depletion). The software OPEN 
LCA 1.5.0 beta 1, developed by Green Delta (http:/ /www.openlca.org/), was used to calculate the overall emissions associated with the pelletization process.

\subsection{Comparative LCA of Wood Pellets, Natural Gas and Heavy Fuel Oil as Heat Energy Sourcers}

\section{Comparison of Three Fuel Sources Producing 1 GJ of Energy}

This part of the study consisted of a comparative LCA (cradle-to-grave) of three energy systems: pellets, natural gas and heavy fuel oil. The primary objective was to highlight the environmental performance of pellets produced in Quebec against natural gas and fossil oil.

As a basis for comparison, it was assumed that both fossil fuels were produced in the USA. The Ecoinvent 3.1 database was used to estimate the relative impacts of wood pellet combustion in furnaces, and of natural gas and heavy fuel oil energy systems. The energy sources were selected in accordance with a report comparing the environmental performance of Canadian wood pellets against those of natural gas and heavy fuel oil, which represent the most common forms of energy in North America [24].

This part of the study focused on the same five impact categories as described above but with two additional categories: the Particulate Matter formation and the urban land occupation impact categories. The Particle Matter formation category was added because Particle Matter (PM) formation comes from emissions of dust and other inorganic species. There are two main classes of these PM, (1) primary particulate that is emitted in particle form of gas that rapidly condensates to form particles and (2) secondary particulate that is mainly formed by chemical reactions that occur in the atmosphere and involves the emissions of volatile organic compounds, ammonia and nitrogen oxides. The urban land occupation impact category was considered because it is essential for the provision of ecosystem services, such as biomass production, and for the maintenance of key environmental functions such as soil functions and carbon storage [26]. How land is used is a critical determinant of environmental change and it impacts ecosystem quality (such as biodiversity) and function.

The functional unit that compares the three sources of fuel refers to 1 GJ of heat energy. The cradle-to-grave analysis includes all the steps of the cradle-to-gate analysis as well as the combustion stage, which includes combustion equipment. To ensure the comparability of LCA results between the three sources of fuels, transportation and infrastructure stages were not included. According to Reed et al. [23], it was estimated that 1 tonne of wood pellets would produce up to $17.3 \mathrm{GJ}$ of heat. The combustion efficiency of $80 \%$ was assumed for pellets and natural gas systems. Transportation of pellets has been reported to have a major impact on their energy balance [10]; however, an LCA that included transportation was beyond the scope of this study.

\section{Results and Discussion}

This section summarizes the LCIA for the two (2) pellet producers (all results refer to the functional unit described, i.e., 1 tonne of bagged pellets) in accordance with ISO 14040 [13].

The main results of the environmental profiles in the five impact categories are shown in both Table 3 and Figure 2. Table 3 provides 1 -the total characterization results (per functional unit) per impact category for each producer; and 2-the relative contribution of each sub-process by category of impact for each producer. Figure 2 shows the effect of the process in each impact category for each producer.

The first observation bore on the major impact of the drying process in four out of five categories for Producer 1: CC (82\%), FD (34\%), HT (60\%) and OD (95\%). For Producer 2, the pelletizing and packing processes had the greatest impacts, with scores for pelletizing ranging from $19 \%$ to $49 \%$ depending on impact categories, while they ranged from $3 \%$ to $66 \%$ for the packing sub-process. Considering all five impact categories, it can be concluded that the grinding and cooling sub-processes are not significantly harmful to the environment. 
Table 3. Characterization results (per functional unit) as well as relative contribution per sub-process involved in the manufacture of pellets. Acronyms: Climate Change (CC), Fossil Depletion (FD), Human Toxicity (HT), Ozone Depletion (OD), Water Depletion (WD) and Equivalent (eq.).

\begin{tabular}{|c|c|c|c|c|c|c|c|c|c|c|}
\hline \multirow[b]{2}{*}{ Category } & \multicolumn{5}{|c|}{ Producer 1} & \multicolumn{5}{|c|}{ Producer 2} \\
\hline & $\begin{array}{l}\mathrm{CC} \\
\mathrm{kg} \mathrm{CO} 2 \\
\text { eq. }\end{array}$ & $\begin{array}{l}\text { FD } \\
\text { kg oil eq. }\end{array}$ & $\begin{array}{l}\text { HT } \\
\text { kg 1,4-DB } \\
\text { eq. }\end{array}$ & $\begin{array}{l}\text { OD } \\
\text { kg CFC-11 } \\
\text { eq. }\end{array}$ & $W D m^{3}$ & $\begin{array}{l}\mathrm{CC} \\
\mathrm{kg} \mathrm{CO} 2 \\
\text { eq. }\end{array}$ & $\begin{array}{l}\text { FD kg oil } \\
\text { eq. }\end{array}$ & $\begin{array}{l}\text { HT } \\
\text { kg 1,4-DB } \\
\text { eq. }\end{array}$ & $\begin{array}{l}\text { OD } \\
\text { kg CFC-11 } \\
\text { eq. }\end{array}$ & WD $\mathrm{m}^{3}$ \\
\hline Total & 20.25 & $6.75 \times 10^{-3}$ & 0.269 & $1.45 \times 10^{-5}$ & $7.03 \times 10^{3}$ & 2.85 & $3.62 \times 10^{-3}$ & $7.84 \times 10^{-2}$ & $4.56 \times 10^{-7}$ & $4.01 \times 10^{3}$ \\
\hline \multicolumn{11}{|c|}{ Sub-process (\%) } \\
\hline Drying & 82.76 & 34.73 & 60.93 & 95.87 & 15.32 & 10.55 & 13.60 & 9.99 & 13.24 & 31.19 \\
\hline Grinding & 0.98 & 5.29 & 2.11 & 0.30 & 12.72 & 3.33 & 4.55 & 3.52 & 4.74 & 10.34 \\
\hline Pelletizing & 7.36 & 32.23 & 22.17 & 2.91 & 69.64 & 19.92 & 22.65 & 18.93 & 26.26 & 49.28 \\
\hline Cooling & 0.19 & 0.74 & 0.61 & 0.10 & 1.47 & 2.04 & 2.80 & 2.16 & 2.90 & 6.38 \\
\hline Packing & 8.71 & 27.01 & 14.18 & 0.82 & 0.85 & 64.14 & 56.39 & 65.39 & 52.86 & 2.81 \\
\hline
\end{tabular}

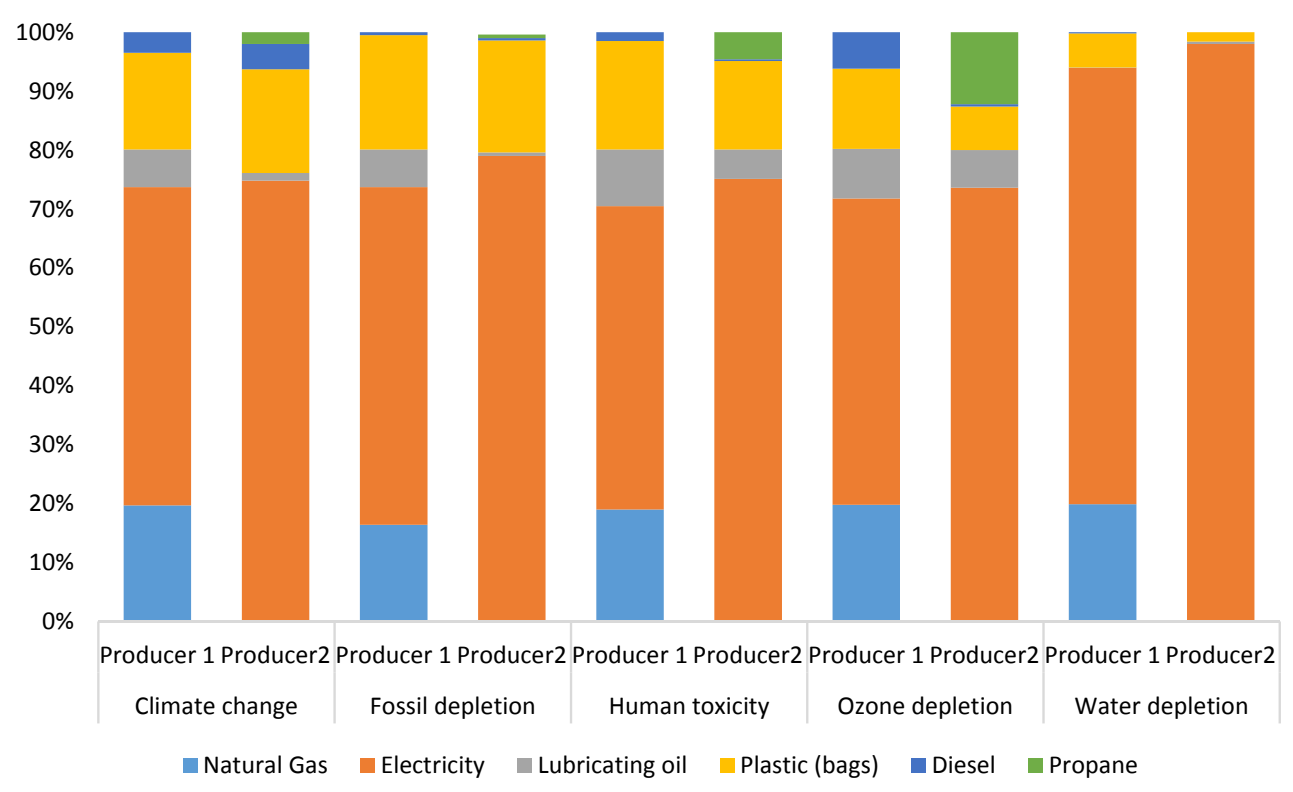

Figure 2. Impact distribution in each category for the two participating plants.

\subsection{Products and Processes Associated to Impact Categories}

The input demand in terms of resources and products (e.g., plastic bags, lubricating oil, water, etc.) for manufacturing wood pellets was relatively low since the raw material consisted of wood chips, sawdust and shavings, all by-products from sawmill operations. In this life cycle approach, all processes require electricity or other types of energy, so that the resource demand was relatively important. Contribution percentages are illustrated in Figure 2. As can be seen, the use and production of electricity generated the highest impact in all categories (ranging from 52\% to 98\%). Electrical energy is required for all equipment and processes involved in the production of wood pellets: drying, grinding, pelletizing, cooling and bagging, packaging machine, conveyors (for distribution of materials) and dust collectors. Given that, in Quebec, power is mainly derived from hydroelectric sources, the use of electricity dominated the water depletion $\left(\mathrm{m}^{3}\right)$ impact category. The use of plastic, mainly employed for bagging wood pellets, represents between $2 \%$ and $19 \%$ depending on the category.

\subsection{Climate Change}

Impacts on climate change were mainly due to emissions of carbon dioxide or methane associated with the use and production of electricity, natural gas and oil. As can be seen in Figure 3 below, the production of 1 tonne of packed pellets implied emissions of $20.25 \mathrm{~kg} \mathrm{CO}_{2}$ eq. for Producer 1 , and $2.84 \mathrm{~kg} \mathrm{CO} 2$ eq. for Producer 2. 


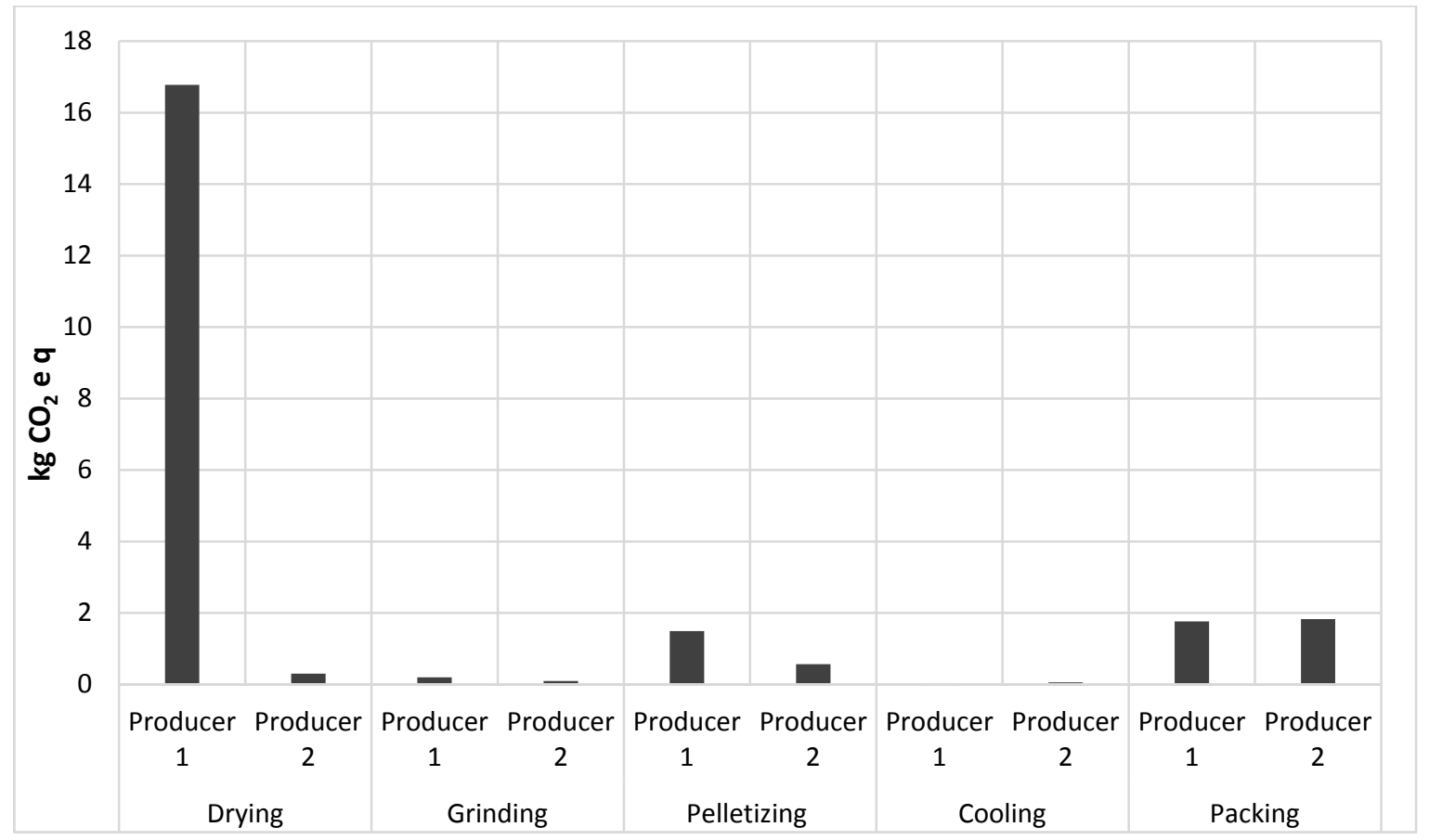

Figure 3. Climate change impacts $\left(\mathrm{kg} \mathrm{CO}_{2}\right.$ eq.) in each sub-process for the two producers.

With Producer 1, the drying stage contributed the most to climate change with $82 \%$ (Table 3) (16.8 $\mathrm{kg} \mathrm{CO}_{2}$ eq., Figure 3), while the bagging stage was the most harmful for Producer 2 with $64 \%$ (Table 3) (1.82 $\mathrm{kg} \mathrm{CO}_{2}$ eq., Figure 3). Note that the main difference between the two producers in the drying stage was the use of natural gas. To produce 1 tonne of wood pellets, Producer 1 used $37.5 \mathrm{~m}^{3}$ of natural gas, which is equivalent to $1400 \mathrm{MJ}$, while Producer 2 did not use any gas. The use of plastic (bags) at the packing stage also contributed to $\mathrm{CO}_{2}$ emissions with both producers. On the other hand, the contributions of the other stages to climate change were much less important. A slight difference between the two producers was observed at the pelletizing stage: $7 \%$ and $20 \%$ for Producer 1 and Producer 2 respectively (Table 3) (Producer $1=1.49 \mathrm{~kg} \mathrm{CO}_{2}$ eq., Producer $2=0.56 \mathrm{~kg} \mathrm{CO}_{2}$ eq., Figure 3). This was due to a difference in energy consumption: $114 \mathrm{kWh}$ for Producer 1 and $46 \mathrm{kWh}$ for Producer 2.

\subsection{Fossil Depletion}

For the fossil fuel depletion category, the production and use of plastic bags and the production and use of fuels such as propane and fuel oil were by far the largest factors. The total fossil fuel depletion factor in the production of one tonne of wood pellets was higher at Producer 1 than at Producer 2 (Producer $1=6.7 \times 10^{-3} \mathrm{~kg}$ oil eq., Producer $2=3.6 \times 10^{-3} \mathrm{~kg}$ oil eq., Figure 4 ).

The sub-processes that contributed the most to fossil fuel depletion included pelletizing with $32 \%$ and 22\% for Producers 1 and 2 respectively (Table 3) (Producer $1=2.1 \times 10^{-3} \mathrm{~kg}$ oil eq., Producer 2 $=8.1 \times 10^{-4} \mathrm{~kg}$ oil eq., Figure 4); packing with $27 \%$ for Producer 1 and $56 \%$ for Producer 2 (Table 3) (Producer $1=1.8 \times 10^{-3} \mathrm{~kg}$ oil eq, Producer $2=2.0 \times 10^{-3} \mathrm{~kg}$ oil eq., Figure 4 ); and drying with $34 \%$ and $13 \%$ for Producers 1 and 2, respectively (Table 3) (Producer $1=2.3 \times 10^{-3} \mathrm{~kg}$ oil eq., Producer $2=$ $4.9 \times 10^{-4} \mathrm{~kg}$ oil eq., Figure 4). The use of natural gas by Producer 1 at the drying stage was the main contributor to this impact category. Overall, the cooling stage $0.5 \%$ and $2.5 \%$ contributed the least to fossil fuel depletion with both producers. 


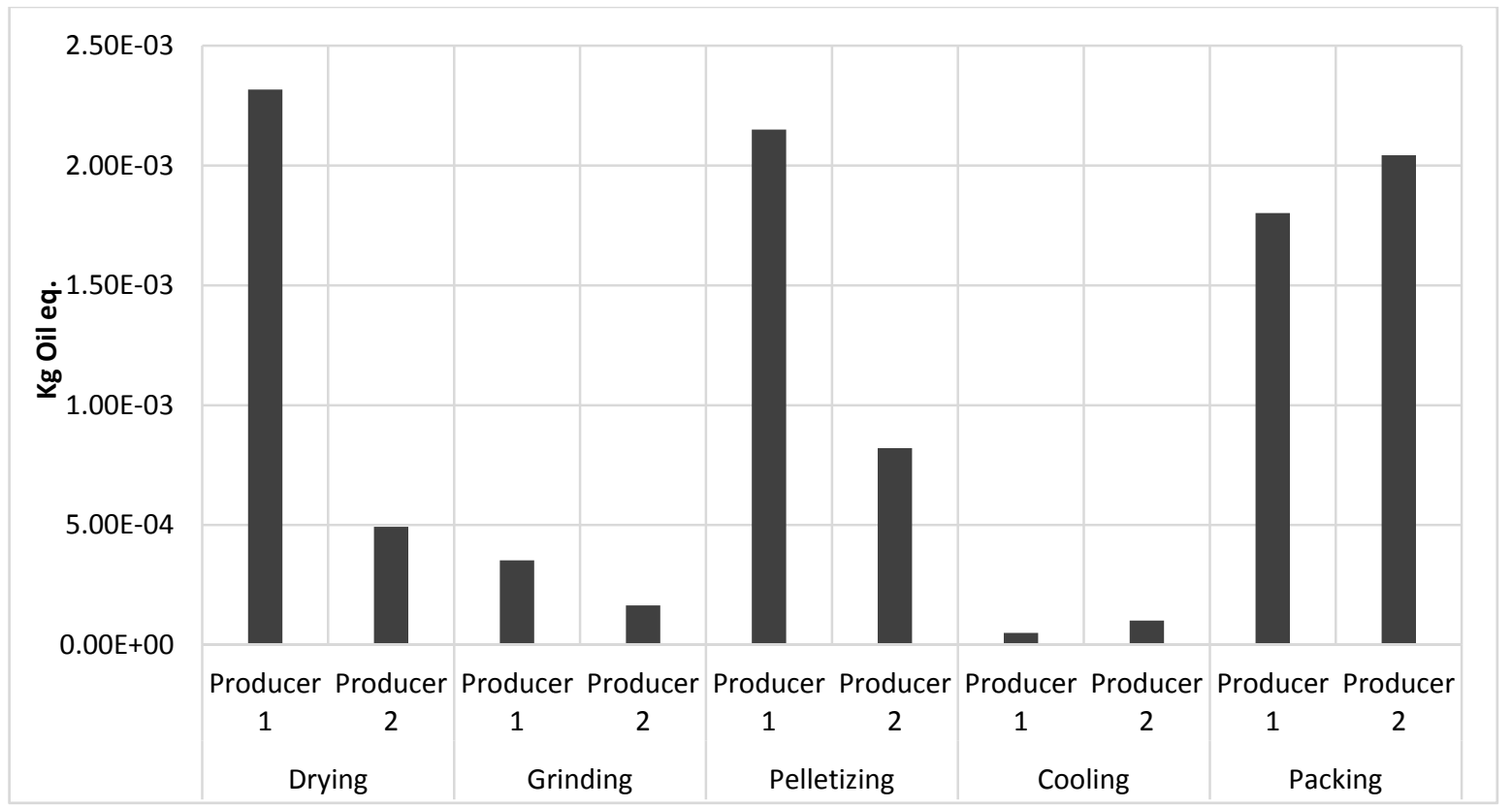

Figure 4. Fossil fuel depletion contribution (kg Oil eq.) in each sub-process for the two producers.

\subsection{Human Toxicity}

The human toxicity category reflects a complex mix of factors known to cause health problems. Both facilities contributed to the human toxicity impact but higher impacts were generated by Producer 1 than by Producer 2 (producer $1=0.25 \mathrm{~kg}$ 1,4-DB eq., producer $2=0.08 \mathrm{~kg}$ 1,4-DB eq., Figure 5). The main contributors to the increase in human toxicity were the packing stage, with scores ranging from $14 \%$ to 65\% with producers 1 and 2 (Table 3) (Producer $1=0.04 \mathrm{~kg}$ 1,4-DB eq. and Producer $2=0.05 \mathrm{~kg}$ 1,4-DB eq., Figure 5); and the drying process with $60 \%$ and $10 \%$ for producers 1 and 2, respectively (Table 3 ) (Producer $1=0.16 \mathrm{~kg}$ 1,4-DB eq. and Producer $2=0.007 \mathrm{~kg}$ 1,4-DB eq., Figure 5).

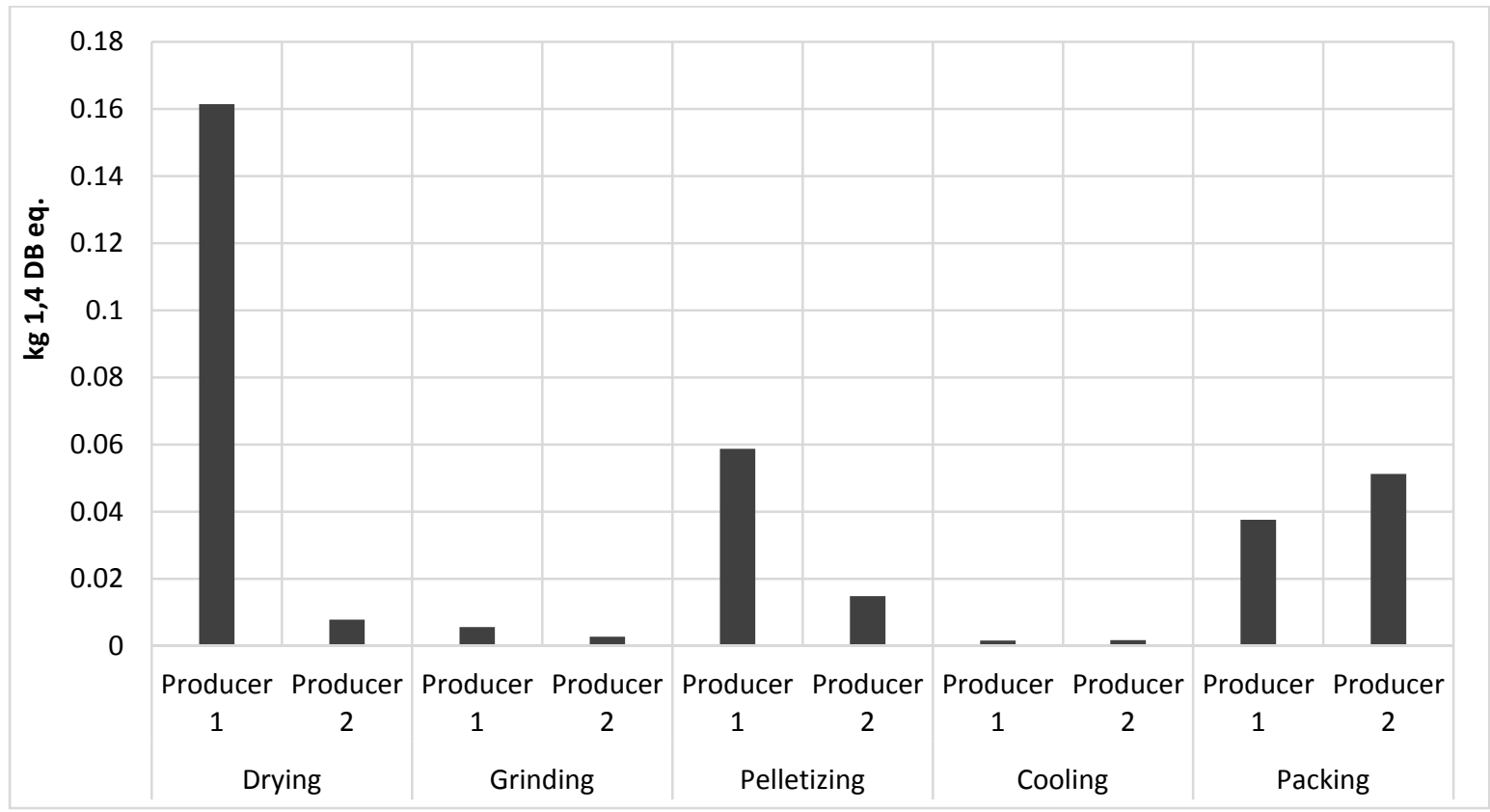

Figure 5. Human toxicity contribution (kg 1,4-DB eq.) in each sub-process for the two producers. 
The drying process was the largest contributor to human toxicity, especially with Producer 1 . This impact was largely influenced by the use of electricity and natural gas. In the packing stage, the use of electricity and the production of plastic bags were the main contributors to human toxicity for both producers. Producer 1 used a robot for the entire process while Producer 2 bagged the pellets manually. It appeared that Producer 2 had the largest impact due to the propane consumption of the forklift used to store the bags in the yard. The impacts at the grinding and cooling stages proved relatively small for both producers. There is a direct relationship between the amounts of fuel combusted in the supply chain with concentrations in air, water and air quality linked to human health [27].

\subsection{Ozone Depletion}

The ozone depletion potential is reported in terms of trichlorofluoromethane equivalent emissions ( $\mathrm{kg}$ CFC-11) and the trend obtained was similar to that observed with climate change. As shown in Figure 6, total contributions to the alteration of the ozone layer were higher with Producer 1 than with Producer 2 (Producer $1=1.45 \times 10^{-5} \mathrm{~kg}$ CFC-11 eq., Producer $2=4.54 \times 10^{-7} \mathrm{~kg} \mathrm{CFC-11} \mathrm{eq.).}$ For Producer 1, the use of natural gas at the drying stage $\left(1.38 \times 10^{-5} \mathrm{~kg}\right.$ CFC-11 eq.) was the most important factor $(95 \%$, Table 3$)$ whereas, for Producer 2, the use of plastic at the packing stage caused the highest impact (52\%, Table 3) $\left(2.41 \times 10^{-7} \mathrm{~kg}\right.$ CFC-11 eq.). Overall, the remaining contributions were almost equally distributed between the other three sub-processes with both producers. The major substances involved in this category were halon 1211 (70\%), halon $1301(22 \%)$ and CFC-114, as reported by [12].

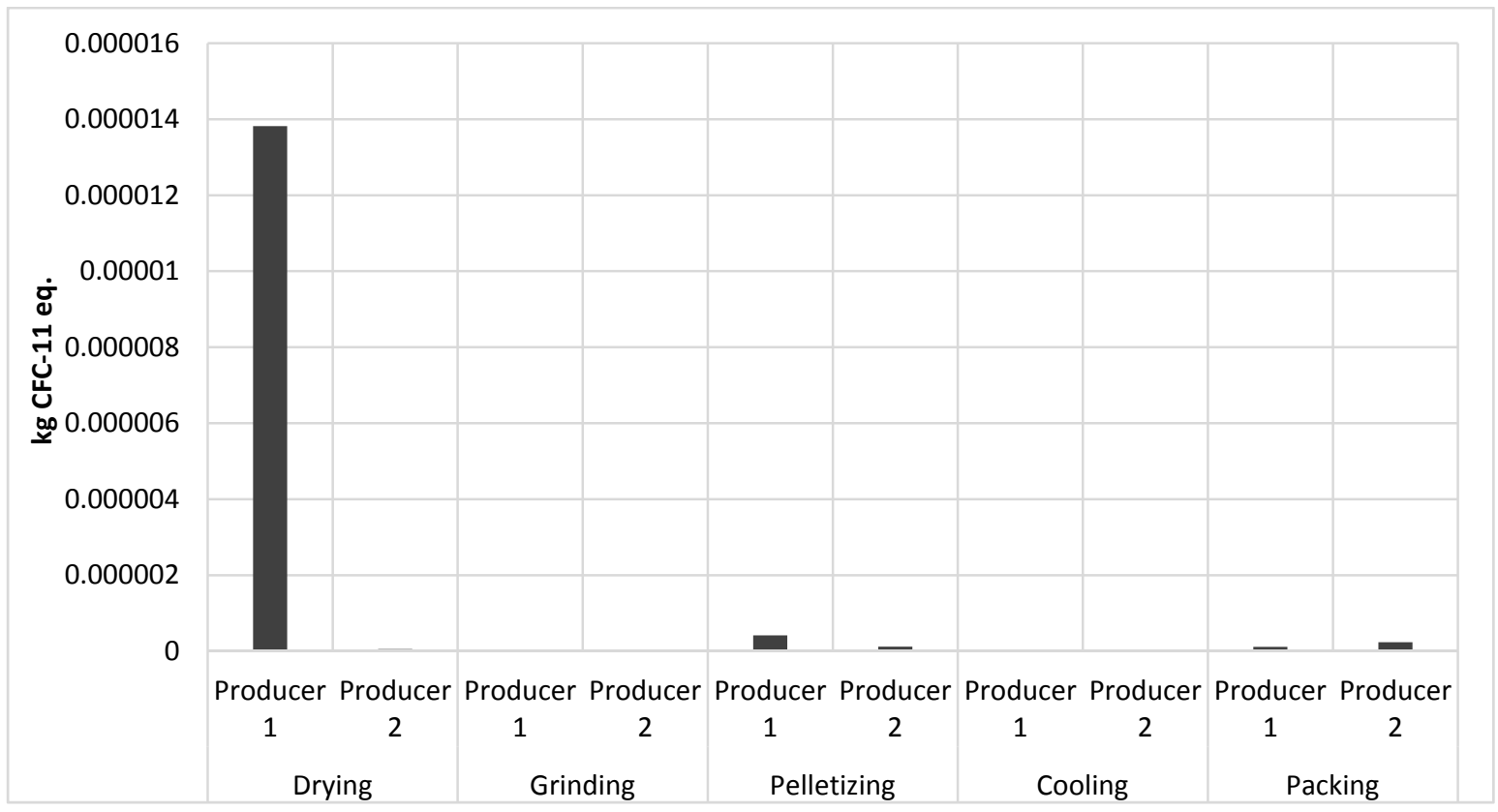

Figure 6. Ozone depletion (kg CFC-11 eq.) in each sub-process for the two producers.

\subsection{Water Depletion}

This impact category simply expresses the total amount of water used (but not the water consumption) from lakes, rivers or wells; in this case it is closely linked to the production of electricity since, in Quebec, it is mainly produced from hydro sources. An important issue to consider is that this water use is mostly released back into the same water shed without a change in water quality, however, the impacts generated and evaluated for water use as mainly related to the water that is not released into the same water shed due to evaporation, evapotranspiration, product incorporation and discharge into another watershed. 
The impact for water depletion was $7029 \mathrm{~m}^{3} \mathrm{H}_{2} \mathrm{O}$ for Producer 1 and $4007 \mathrm{~m}^{3} \mathrm{H}_{2} \mathrm{O}$ for Producer 2 (Figure 7). The main contributor to depletion of water reserves was the pelletizing stage, at $70 \%$ and $50 \%$ with Producers 1 and 2, respectively (Table 3) (Producer $1=4895 \mathrm{~m}^{3}$, Producer $2=1975 \mathrm{~m}^{3}$ ). As observed on Figure 7, Producer 1 used more than twice the amount of water used by Producer 2 at the pelletizing stage. Hardwood is often more difficult to pelletize than softwood, and requires more water. On the other hand, drying with natural gas (Producer $1=1077 \mathrm{~m}^{3}$ ) appeared to be slightly less damaging in terms of water depletion than drying with sawdust and wood planks (or shavings and wood chips) (Producer $2=1250 \mathrm{~m}^{3}$ ). The larger quantities of particles to be milled at Producer 1 , compared to Producer 2, contributed to the use of much electricity and thus a larger reduction in water reserves, mainly related to hydroelectricity (Producer $1=894 \mathrm{~m}^{3}$, Producer $2=414 \mathrm{~m}^{3}$ ).

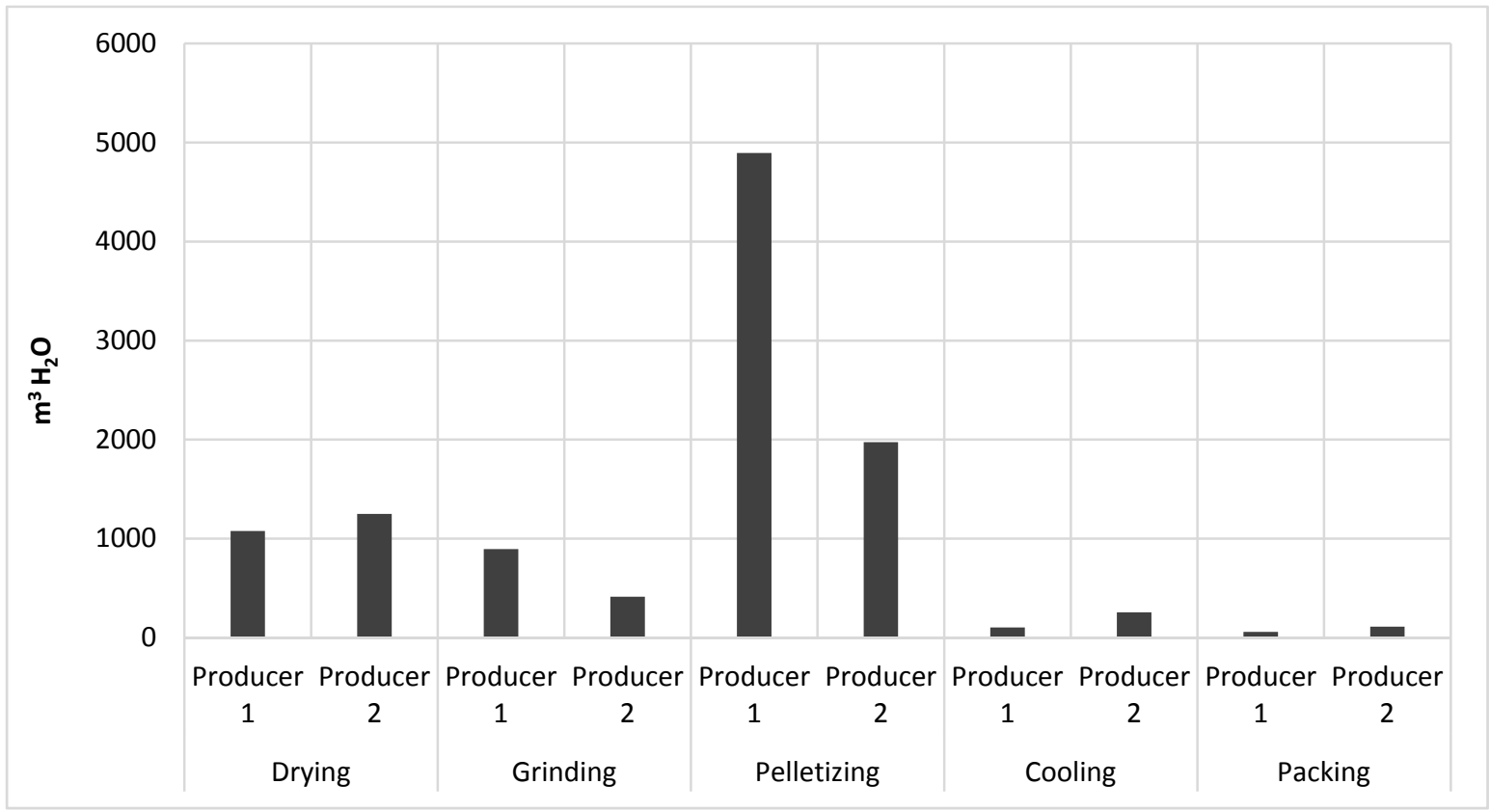

Figure 7. Water depletion $\left(\mathrm{m}^{3} \mathrm{H}_{2} \mathrm{O}\right)$ in each sub-process for the two producers.

It should be highlighted that water used for hydroelectricity is qualitatively different from water used in other major energy systems: consumption is associated with evaporation and unrecoverable seepage from reservoirs behind dams rather than with extractive and cooling operations.

\subsection{Comparative LCA of Wood Pellets, Natural Gas and Heavy Fuel Oil as Heat Energy Sourcers}

Performance of Wood Pellets as Compared to that of Natural Gas and Fuel Oil (Cradle-to-Grave)

Figure 8 displays the results of a comparison between three energy systems: wood pellets, natural gas and heavy fuel oil in the generation of $1 \mathrm{GJ}$ of energy. The comparative LCIA results of the life cycle environmental impacts are expressed as percentages in relation to fossil fuels as a reference (index $=$ $100 \%$ for each impact category) for all impact categories except water depletion. Overall, the pellet energy system outperformed the natural gas and fossil oil systems in four out of five impact categories.

The highest environmental impact reductions from replacing heavy fuel oil with wood pellets by producers 1 and 2 respectively were observed in the climate change category ( $96 \%$ to $98 \%$, Figure 8 ) (3.245 and $0.733 \mathrm{~kg} \mathrm{CO}_{2}$ eq., Table 4); the ozone depletion category (94\% to $99 \%$, Figure 8$)\left(8.38 \times 10^{-7}\right.$ and $1.86 \times 10^{-7} \mathrm{~kg} \mathrm{CFC}-11$ eq., Table 4$)$; and the human toxicity category ( $93 \%$ to $98 \%$, Figure 8 ) $\left(1.02 \times 10^{-1}\right.$ and $3.08 \times 10^{-2} \mathrm{~kg} 1$,4-DB eq., Table 4). The environmental impact reduction in the fossil depletion category was also important but less remarkable and was set at $65 \%$ to $85 \%$ (Figure 8 ) $\left(7.30 \times 10^{-4}\right.$ and $3.16 \times 10^{-3} \mathrm{~kg}$ oil eq., Table 4$)$. These results agree with the trend reported by 
Perilhon et al. [28]. Xu et al. [29] also compared the environmental performance of different ways to produce electricity and concluded that wood, when used as a renewable energy source (i.e., from sustainably managed forests), is particularly useful in reducing greenhouse gas emissions. Moreover, wood is an economically viable energy source in most cases.

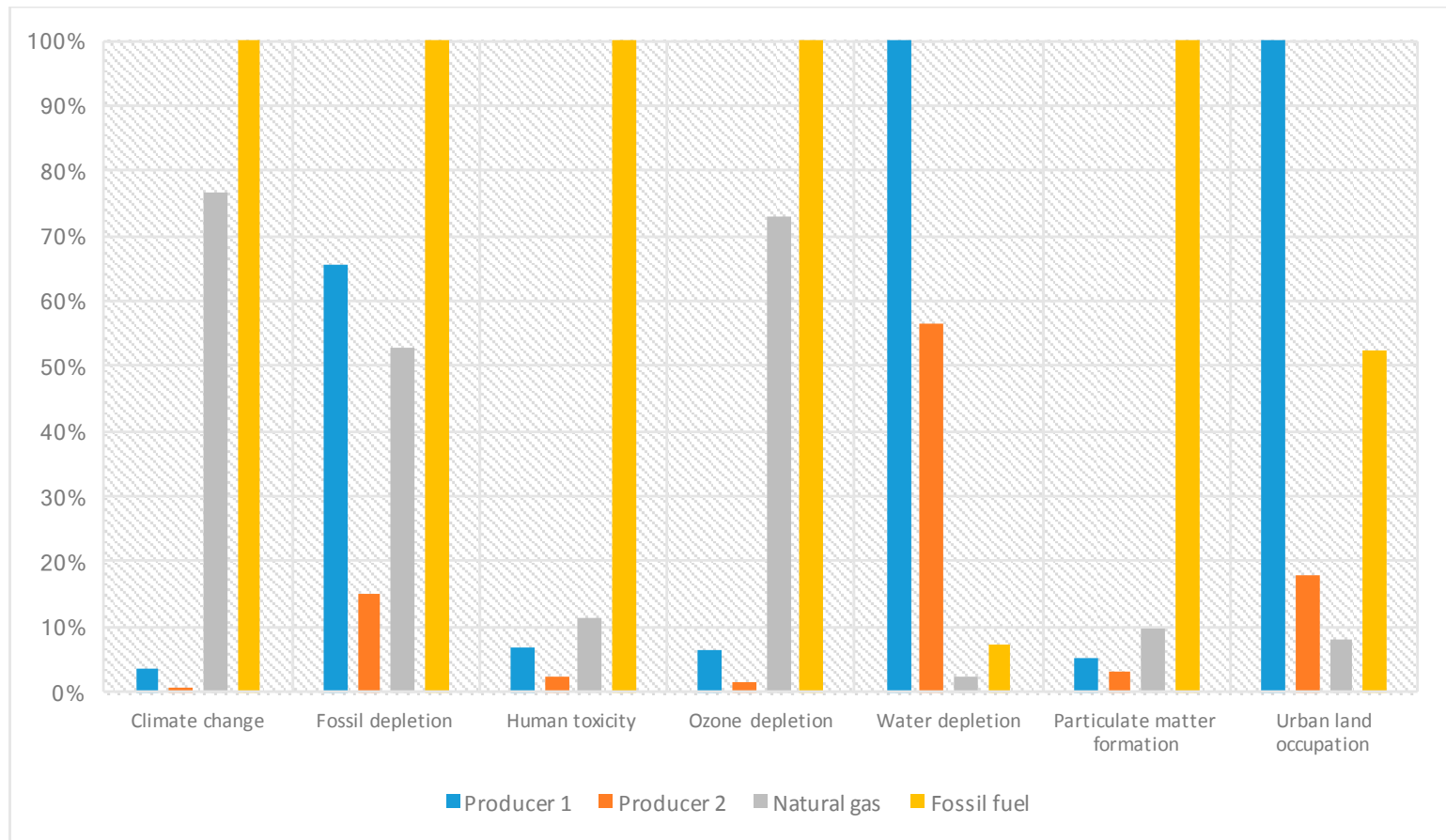

Figure 8. Distribution ratios of impacts in both pellets producers. Results normalized considering Fossil fuels as reference. Index $=100 \%$ for each impact category. For water depletion Producer 1 served as a reference.

Table 4. Environmental impact of the different energy systems in the production of 1 GJ of energy.

\begin{tabular}{cccccc}
\hline Impact Categories & Units & $\begin{array}{c}\text { Wood Pellet } \\
\text { Producer 1 }\end{array}$ & $\begin{array}{c}\text { Wood Pellet } \\
\text { Producer 2 }\end{array}$ & Natural Gas & Fossil Oil \\
\hline Climate change & $\mathrm{Kg} \mathrm{CO}_{2}$ eq. & 3.245 & 0.733 & 71.013 & 92.623 \\
Fossil depletion & $\mathrm{Kg} \mathrm{Oil} \mathrm{eq.}$ & $3.16 \times 10^{-3}$ & $7.30 \times 10^{-4}$ & $2.54 \times 10^{-3}$ & $4.82 \times 10^{-3}$ \\
Human toxicity & $\mathrm{Kg} \mathrm{1,4-DB} \mathrm{eq.}$ & $1.02 \times 10^{-1}$ & $3.08 \times 10^{-2}$ & $1.69 \times 10^{-1}$ & 1.48 \\
Ozone depletion & $\mathrm{Kg} \mathrm{CFC-11}$ & $8.38 \times 10^{-7}$ & $1.86 \times 10^{-7}$ & $9.90 \times 10^{-6}$ & $1.36 \times 10^{-5}$ \\
Water depletion & $\mathrm{m}^{3} \mathrm{H}_{2} \mathrm{O}$ & 364.110 & 206.284 & 7.771 & 25.956 \\
Particulate matter formation & $\mathrm{kg} \mathrm{PM10} \mathrm{eq.}^{2}$ & $8.64 \times 10^{-3}$ & $5.40 \times 10^{-3}$ & $1.60 \times 10^{-2}$ & $1.68 \times 10^{-1}$ \\
Urban land occupation & $\mathrm{m}^{2}$ & $2.28 \times 10^{-1}$ & $4.06 \times 10^{-2}$ & $1.81 \times 10^{-2}$ & $1.20 \times 10^{-1}$ \\
\hline
\end{tabular}

The impact on water depletion in a facility using electricity from hydro sources was the main reason for choosing Producer 1 as a reference (index $=100 \%$ ) in this impact category. The results show a $93 \%$ to $98 \%$ reduction (Figure 8 ) in the consumption of water resources (206.2 and $364.1 \mathrm{~m}^{3} \mathrm{H}_{2} \mathrm{O}$, Table 4) for producing $1 \mathrm{GJ}$ of electricity with wood pellets (both producers) over natural gas and heavy fuel oil.

For Particle Matter (PM) formation comes from emissions of dust and another inorganic species. They are two main classes of these PM, (1) primary particulate that is emitted in particle form of gas that rapidly condensates to form particles and (2) secondary particulate that is mainly formed by chemical reactions that occur in the atmosphere and involves the emissions of volatile organic compounds, ammonia and nitrogen oxides. In general terms, the impact of PM formation fossil fuel produces the highest PM due to emissions of precursors of secondary particle and to the combustion of fossil fuels, whereas the impact of the manufacturing and combustion processes are mainly associated 
with direct emissions of dust in the atmosphere. The emissions caused by pellets production are mainly due to the combustion of the raw material used for drying.

The urban land occupation $\left(\mathrm{m}^{2}\right)$ impact category is predominated by producer $1\left(2.228 \times 10^{-1} \mathrm{~m}^{2}\right)$ for producing $1 \mathrm{GJ}$ of energy, while natural gas produces the fewest land occupation to produced 1 GJ of energy. This is due to the fact that the natural land transformation of $1 \mathrm{GJ}$ of heat produced by pellets is much higher than the ones produced by natural gas or fossil fuel., although producer 2 causes the lower urban land occupation than fossil fuel, the ratio between land transformation and heat produced is less favorable for pellets producers.

Overall, the wood pellet energy system in Producer 2 consumed the lowest amount of energy among all systems compared, and this primary energy demand was coming from renewable sources. Thus, replacing fossil fuel with wood pellets contributes to achieving sustainability in terms of energy productions systems [20].

However, important attention should be paid to carbon neutrality of bioenergy which, in this case, comes from wood pellets. This subject has become a matter of debate since wood emits more $\mathrm{CO}_{2}$ than fossil fuels per unit of energy released [30]; the release of $\mathrm{CO}_{2}$ is much faster when wood is combusted than when wood undergoes natural decomposition and $\mathrm{CO}_{2}$ recapture by vegetation is not immediate and is usually achieved on decade-to-century-long timescales.

Based on the above, the key environmental issue of using bioenergy from forest residues is the time (delay) which cumulative $\mathrm{CO}_{2}$ emissions to the atmosphere from an energy plant are greater for bioenergy than for fossil fuel. The delay before environmental benefits are achieved has been referred to as payback time. It has been demonstrated that using silviculture to increase the tree growth rate in the regenerating stand could improve the performance of this feedstock source and generate atmospheric benefits within a shorter time frame.

In Canada, for example, $\mathrm{CO}_{2}$ emissions benefit range, from instant atmospheric to payback times over 100 years. Quebec, Laganiere et al. [31] determined that using bioenergy to replace fossil fuels, from harvest residues burned at roadside, generates immediate atmospheric benefits (payback time $=$ 0 year). Therefore, beyond the limitations of this study and the payback time of environmental benefits, residue-based bioenergy in the form of sawmill residues appeared a suitable feedstock for mitigating GHG emissions in a short time frame.

\section{Final Remarks}

The results reported in the previous section clearly showed that the consumption of electricity for wood pellet production had the greatest environmental impact, with reporting ratios ranging from $52 \%$ to $98 \%$, depending on impact categories. The most important activities requiring electricity were grinding, pelletizing and packaging, which was reported by Gustavsson and Karlsson, and Cespi et al. [32,33].

However, such heavy reliance on electricity does not cause severe environmental impacts due to the renewable nature of the electricity provided by the Quebec grid. Indeed, $98 \%$ of the Quebec energy mix is derived from hydro sources, which entail low environmental burdens. In fact, the largest wood pellet producing and consuming countries around the world are also some of the highest producers and users of renewable energy, including Sweden, Denmark, the United States and The Netherlands [34].

It should be noted that hydroelectricity also has environmental effects that should not be overlooked. The most important issues to be considered are associated with biodiversity limitation, impacts on fauna and flora, landscape intrusion and water resource. This is due in a large part to direct damage caused by the impact of building dams [35].

Our results also demonstrated the benefits of using renewable sources of energy (in the form of sawdust, shavings and wood chips) over natural gas and fossil fuels, especially at the drying stage. However, the absence of the transportation step as part of our LCA analysis limit the current technological representativeness of the findings of this study. An LCA grade to grade approach could 
help improve the representativeness and the comparison between wood pellets and the other types of fuels. Failure to perform a sensitivity analysis on the types of the equipment (furnaces and boilers) and their capacities due to lack of data is another limitation. In the future, the replacement of fossil fuels and natural gas with renewable energy sources or new blends could help reduce the impact on the environment.

Although there are limitations to this research, since this is a gate-to-gate approach, the results indicate that, in Quebec, wood pellets offer many advantages from an LCA standpoint over non-renewable fuels. The use of wood pellets would reduce energy, would produce less hazardous emissions which results in less impacts that affects human health and helps to mitigate climate change; these facts are consistent with several previous studies [3,25,26,36]. However, it is important to produce and use pellets responsibly, since an indiscriminate production of them would be translated into emissions of particles and may lead to more intensive forest management which leads to greater impacts on biodiversity and ecosystems [37].

Understanding the fact that global impacts come not only from pellets burning or production but also from transportation processes, one needs to conduct a streamlined life cycle analysis in order to determine whether biomass utilization via pelletization and exportation still remains sustainable. In this sense, Magelli et al., [10] found that about 2.6 GJ of energy is associated with long-distance $(15,500 \mathrm{~km})$ ocean transportation. Thus, the local market should be explored to reduce the energy consumption associated with wood pellet transportation over long distances.

This study highlighted the importance of choosing the right source of energy to limit environmental concerns. Undoubtedly, the methods used to produce either heat or electricity play a fundamental role in achieving better environmental performance, but also in achieving sustainability and renewability goals at the local scale in the province of Quebec. Based on the above, it is clear that particular emphasis must be placed on wood pellets as a renewable source of energy, with due consideration to the need for sustainable forest management.

With respect to the potential of wood pellets to mitigate carbon, it must be stated that all carbon emissions are significant, whether biogenic or from non-renewable fossil fuels. Assuming that wood pellets are made of a woody biomass, the carbon contained within the wood would remain in the biogenic carbon cycle, yielding only net atmospheric carbon emissions associated with the fossil fuels used in biomass fuel processing. Under this assumption, the replacement of fossil fuel and natural gas with wood pellets would result in reducing life cycle atmospheric greenhouse gas emissions. However, special attention must be paid to the fact that, given the relatively short lifetime of wood pellets, the carbon dioxide they store will be soon be released, thus closing the carbon cycle without releasing additional carbon dioxide into the atmosphere. Under the circumstances, it should be fairly reasonable to omit carbon dioxide emissions in an LCA.

Future work should include a more detailed sensitivity analysis on key aspects of this analytical approach, including the efficiency of wood pellet heating devices and the allocation of entrained energy from dry co-products.

To evaluate how wood pellets could be used to reduce (or not reduce) the impact of electricity requirements, different scenarios need to be proposed and compared with the current case study. Because wood pellet plants already work with wood, and use it to meet heating requirements, such scenarios must be built on the use of wood as the primary source to produce all or part of the plant's energy requirements (heat and electricity).

\section{Conclusions}

This study has allowed us to analyze the environmental impacts of producing wood pellets at two Quebec plants.

The use of wood pellets as a source of energy may be an attractive avenue to reducing greenhouse gas emissions and mitigating environmental impacts. However, a proper assessment of the real benefits 
they can provide requires that the environmental impacts involved in their manufacture be taken into account.

This LCA-based study showed that the drying and the pelletizing stages had the greatest impacts on environmental performance. The use of sawdust, shavings and wood chips as a source of fuel for the dryer largely contributed to reducing environmental impact over that entailed by the use of natural gas. In this context, the replacement of electricity by a co-generation unit with biomass could be beneficial in reducing environmental impact.

This assessment also showed to what extent the use of electricity played an essential role in the environmental profile throughout the wood pellet manufacturing process. However, electricity used in Quebec comes from hydro sources, hence its lower contribution to global warming, ozone depletion and fossil fuel consumption as compared to other non-renewable energy sources.

An attractive way to improve pellet performance with respect to electrical consumption might be to produce electricity with a co-generation unit rather than buying it from the grid, and selling any surplus heat to other users in the neighborhood.

The analysis showed that there were no substantial differences in overall performances between the two pellet plants participating in the study. However, Producer 2 showed better environmental performance than Producer 1, where the drying and packing phases contributed more significantly to the overall performance.

A comparison of the environmental footprint of generating $1 \mathrm{GJ}$ of energy from wood pellets produced in the participating Quebec pellet plants as opposed to natural gas and fossil fuel oil demonstrated the advantage of renewable over fossil sources of energy in reducing environmental impacts. This information could serve for similar wood pellet facilities elsewhere in Canada or the United States.

Considering the growing interest in renewable energy (biomass in particular), and the lack of environmental information on wood pellets, this study could be useful not only for forest sector-related industries but also for the energy sector and policymakers.

The information contained in this study should be used as a benchmark for future assessments involving wood pellets or other renewable and non-renewable fuels, since LCA is a powerful tool for comparing various fuel options and allowing for reasonable and informed decisions.

Acknowledgments: This research was financially funded by Quebec Wood Export Bureau. We thank the pellets factories of Quebec for their contributions to the inventory life cycle assessment of this work.

Author Contributions: Alejandro de Jesus Padilla Rivera was the first author on the manuscript and carried out the main data analyses. He was the principal investigator running the life cycle analysis of wood pellet production and helped conducting the survey from the pellets producers. Julie Barrette was the second author and contributed substantially to the manuscript. She conducted the survey of pellet producers and was involved in the interpretation of the life cycle analysis. Pierre Blanchet was involved in the supervision of the project. He helped defining the system boundary of the life cycle inventory analysis and to revise the manuscript. He was also involved in the interpretation and presentation of the life cycle analysis results. Evelyne Thiffault was the main supervisor of the project. She was involved in the project conception and helped to revise the manuscript.

Conflicts of Interest: The authors declare no conflict of interest.

\section{References}

1. Uslu, A.; Faaij, A.P.C.; Bergman, P.C.A. Pre-treatment technologies, and their effect on international bioenergy supply chain logistics. Techno-economic evaluation of torrefaction, fast pyrolysis and pelletisation. Energy 2008, 33, 1206-1223. [CrossRef]

2. Chum, H.; Faaij, A.; Moreira, J.; Berndes, G.; Dhamija, P. IPCC Special Report on Renewable Energy Sources and Climate Change Mitigation (SRREN); World Bank Group: Washington, DC, USA, 2011.

3. IEA (International Energy Agency). Energy Technology Perspectives; International Energy Agency: Paris, France, 2010.

4. Barbosa, A.; Brusca, I. Governance structures and their impact on tariff levels of Brazilian water and sanitation corporations. Util. Policy 2015, 34, 94-105. [CrossRef] 
5. Lamers, P.; Junginger, M.; Hamelinck, C.; Faaij, A. Developments in international solid biofuel trade-An analysis of volumes, policies, and market factors. Renew. Sustain. Energy Rev. 2012, 16, 3176-3199. [CrossRef]

6. Saidur, R.; Abdelaziz, E.A.; Demirbas, A.; Hossain, M.S.; Mekhilef, S. A review on biomass as a fuel for boilers. Renew. Sustain. Energy Rev. 2011, 15, 2262-2289. [CrossRef]

7. Sikkema, R.; Steiner, M.; Junginger, M.; Hiegl, W.; Hansen, M.T.; Faaij, A. The European wood pellet markets: current status and prospects for 2020. Biofuels Bioprod. Biorefining 2011, 5, 250-278. [CrossRef]

8. Guo, M.; Song, W.; Buhain, J. Bioenergy and biofuels: History, status, and perspective. Renew. Sustain. Energy Rev. 2015, 42, 712-725. [CrossRef]

9. Kylili, A.; Christoforou, E.; Fokaides, P.A. Environmental evaluation of biomass pelleting using life cycle assessment. Biomass Bioenergy 2016, 84, 107-117. [CrossRef]

10. Magelli, F.; Boucher, K.; Bi, H.T.; Melin, S.; Bonoli, A. An environmental impact assessment of exported wood pellets from Canada to Europe. Biomass Bioenergy 2009, 33, 434-441. [CrossRef]

11. Monteleone, B.; Chiesa, M.; Marzuoli, R.; Verma, V.K.; Schwarz, M.; Carlon, E.; Schmidl, C.; Ballarin Denti, A. Life cycle analysis of small scale pellet boilers characterized by high efficiency and low emissions. Appl. Energy 2015, 155, 160-170. [CrossRef]

12. Laschi, A.; Marchi, E.; González-García, S. Environmental performance of wood pellets' production through life cycle analysis. Energy 2016, 103, 469-480. [CrossRef]

13. International Organization for Standardization (ISO). ISO 14040:2006—Environmental Management-Life Cycle Assessment-Principles and Framework; International Organization for Standardization: Geneva, Switzerland, 2006.

14. CanBio. CanBio Report on the Status of Bioenergy in Canada; Forest Products Association of Canada: Ottawa, ON, Canada, 2014.

15. Barrette, J.; Thiffault, E.; Achim, A.; Junginger, M.; Pothier, D.; De Grandpré, L. A financial analysis of the potential of dead trees from the boreal forest of eastern Canada to serve as feedstock for wood pellet export. Appl. Energy 2017, 198, 410-425. [CrossRef]

16. Krigstin, S.; Hayashi, K.; Tchórzewski, J.; Wetzel, S. Current inventory and modelling of sawmill residues in Eastern Canada. For. Chron. 2012, 88, 626-635. [CrossRef]

17. Ackom, E.K.; Mabee, W.E.; Saddler, J.N. Industrial Sustainability of Competing Wood Energy Options in Canada. Appl. Biochem. Biotechnol. 2010, 162, 2259-2272. [CrossRef] [PubMed]

18. Barrette, J.; Thiffault, E.; Saint-Pierre, F.; Wetzel, S.; Duchesne, I.; Krigstin, S. Dynamics of dead tree degradation and shelf-life following natural disturbances: Can salvaged trees from boreal forests "fuel" the forestry and bioenergy sectors? Forestry 2015, 88, 275-290. [CrossRef]

19. Murphy, F.; Devlin, G.; McDonnell, K. Greenhouse gas and energy based life cycle analysis of products from the Irish wood processing industry. J. Clean. Prod. 2015, 92, 134-141. [CrossRef]

20. Mahalle, L. Comparative Life Cycle Assessment of Pellet, Natural Gas and Heavy Fuel Oil as Heat Energy Sources; FPInnovations: Vancouver, BC, Canada, 2013.

21. Goedkoop, M.; Heijungs, R.; Huijbregts, M.; De Schryver, A.; Struijs, J.; Van Zelm, R. ReCiPe 2008 First Edition Report I: Characterisation; Universiteit Leiden: Leiden, The Netherlands, 2009.

22. Wagner, M.; Lewandowski, I. Relevance of environmental impact categories for perennial biomass production. GCB Bioenergy 2017, 9, 215-228. [CrossRef]

23. Reed, D.; Bergman, R.; Kim, J.W.; Taylor, A.; Harper, D.; Jones, D.; Knowles, C.; Puettmann, M.E. Cradle-to-gate life-cycle inventory and impact assessment of wood fuel pellet manufacturing from hardwood flooring residues in the southeastern United States. For. Prod. J. 2012, 62, 280-288. [CrossRef]

24. Mahalle, L.; Lavoie, P.; Meek, P.; McDonald, J. A Comparative Life Cycle Assessment of Canadian Hardwood Flooring with Alternative Flooring Types; FPInnovations: Vancouver, BC, Canada, 2011.

25. Corrado, S. Life Cycle Assessmentof pellets production and combustion chain in the European context, Politecnico di Milano. Ph.D. Thesis, Politecnico di Milano, Milan, Italy, 2011.

26. Allacker, K.; de Souza, D.M.; Sala, S. Land use impact assessment in the construction sector: An analysis of LCIA models and case study application. Int. J. Life Cycle Assess. 2014, 19, 1799-1809. [CrossRef]

27. Wang, J.S. The Health Impacts of Energy Choices; Healthy Energy Initiative Coordinator: Ciudad Autónoma de Buenos Aires, Argentina, 2015. 
28. Perilhon, C.; Alkadee, D.; Descombes, G.; Lacour, S. Life Cycle Assessment Applied to Electricity Generation from Renewable Biomass. Energy Procedia 2012, 18, 165-176. [CrossRef]

29. Xu, C.; Hong, J.; Chen, J.; Han, X.; Lin, C.; Li, X. Is biomass energy really clean? An environmental life-cycle perspective on biomass-based electricity generation in China. J. Clean. Prod. 2016, 133, 767-776. [CrossRef]

30. Walker, T.; Cardellichio, P.; Colnes, A.; Gunn, J.; Kittler, B.; Perschel, B.; Recchia, C.; Saah, D. Massachusetts Biomass Sustainability and Carbon Policy Study: Report to the Commonwealth of Massachusetts Department of Energy Resources; Manomet Center for Conservation Science: Plymouth, MA, USA, 2010.

31. Laganière, J.; Paré, D.; Thiffault, E.; Bernier, P.Y. Range and uncertainties in estimating delays in greenhouse gas mitigation potential of forest bioenergy sourced from Canadian forests. GCB Bioenergy 2017, 9, 358-369. [CrossRef]

32. Gustavsson, L.; Karlsson, A. CO2 mitigation cost: A system perspective on the heating of detached houses with bioenergy or fossil fuels. Energy Policy 2002, 30, 553-574. [CrossRef]

33. Cespi, D.; Passarini, F.; Ciacci, L.; Vassura, I.; Castellani, V.; Collina, E.; Piazzalunga, A.; Morselli, L. Heating systems LCA: Comparison of biomass-based appliances. Int. J. Life Cycle Assess. 2014, 19, 89-99. [CrossRef]

34. Granath, J. The Global Wood Pellet Market; International Energy Agency: Paris, France, 2015.

35. Botelho, A.; Ferreira, P.; Lima, F.; Pinto, L.M.C.; Sousa, S. Assessment of the environmental impacts associated with hydropower. Renew. Sustain. Energy Rev. 2017, 70, 896-904. [CrossRef]

36. Katers, J.F.; Snippen, A.J.; Puettmann, M.E. Life-Cycle Inventory of Wood Pellet Manufacturing and Utilization in Wisconsin. For. Prod. J. 2012, 62, 289-295. [CrossRef]

37. Thiffault, E.; Lorente, M.; Murray, J.; Endres, J.M.; Mccubbins, J.S.N. Ecological sustainability of wood bioenergy feedstock supply chains: Local, national and international policy perspective. Vt. Law Rev. 2013, 1, 283-292.

(c) 2017 by the authors. Licensee MDPI, Basel, Switzerland. This article is an open access article distributed under the terms and conditions of the Creative Commons Attribution (CC BY) license (http:/ / creativecommons.org/licenses/by/4.0/). 